\title{
Finding a Legal Balance between the Right to Strike and Right to Education in Kenya
}

Vicky Aridi*

\begin{abstract}
The teachers' right to strike and the children's right to education are both essential rights recognised by national and international laws in Kenya. Despite this fact, there are instances where conflicts arise between these two rights. The courts have a mandate to balance competing human rights in instances of conflict. However, whenever there has been a conflict between the two rights, Kenyan courts have issued injunctions that require public-school teachers to suspend their strike. By doing so, the courts are leaving the teachers with no effective alternative mechanism to address their pertinent needs. The question of how a balance between the teachers'right to strike and the children's right to education in Kenya can be attained is thus an essential concern that is at the focal point of this paper. In a bid to address this question, Kenya's Constitution, Children's Act, Labour Relations Act, and case law from the Court of Appeal; namely, TSC v KNUT \& 3 others, are analysed to reveal Kenya's position on the two rights and the various balancing approaches available.
\end{abstract}

Key words: The right to strike, the right to education and balancing approach

\section{Introduction}

On one hand, every employee in Kenya is entitled to enjoy the right to strike as espoused in Article 41 of the Constitution of Kenya. ${ }^{1}$ Section 2 of the Labour Relations Act defines a strike as a mechanism of pushing for dispute resolution by the employees. ${ }^{2}$ Moreover, the right to strike serves as an essential mechanism

\footnotetext{
The author is an LLB student at Strathmore University Law School, Nairobi, Kenya.

Article 41(1) (d), Constitution of Kenya, (2010).

Section 2, Labour Relations Act, (No. 14 of 2007).
} 
to defend and ensure adequate working conditions for employees. ${ }^{3}$ On the other hand, Article 53 of the Constitution of Kenya provides that every child has the right to education. ${ }^{4}$ The Constitution further provides that the best interest of the child should be given paramount importance with regard to any matter touching on children's rights. ${ }^{5}$ Both the right to strike and right to education are not absolute and can be limited by law under Article 24 of the Constitution of Kenya. ${ }^{6}$

Currently, public-school teachers exercise the right to strike to compel the State, which is their employer, to address their pertinent needs such as an increase in remuneration. ${ }^{7}$ Further, teachers resort to strikes as a dispute resolution mechanism to unlock an impasse in the collective bargaining process. ${ }^{8}$ However, these strikes result in a limitation to the children's fundamental right to education. This seems to contravene the 'best interest of the child' principle. In January 2009, a landmark teachers' strike resulted in the closure of public schools and affected the right to education of about eight million children. ${ }^{9}$ Further, in September 2015, 28,000 teachers went on strike, which prevented children in public schools from exercising their right to education. ${ }^{10}$

In an attempt to resolve the conflict between these two rights, the Court of Appeal (the highest court to have adjudicated on this conflict) in the case Teachers Service Commission v Kenya National Union of Teachers \& 3 others issued an injunction, ${ }^{11}$ which prevented teachers from exercising their fundamental right to strike and also required them to continue teaching so as to ensure that children enjoy their right to education. ${ }^{12}$

By the Court of Appeal issuing this injunction, it was further preventing public-school teachers from exercising their fundamental right to strike - the main arsenal that they have against the State. These teachers were therefore left without an effective dispute resolution mechanism as their right to strike was limited by the children's right to education. Yet, as this paper will demonstrate,

\footnotetext{
Guido H, Odero A and Gernigon B, 'ILO principles concerning the right to strike' 137, International Labour Review 4, 2000, 13.

Article 53 (1) (b), Constitution of Kenya, (2010).

Article 53 (2), Constitution of Kenya, (2010).

Article 24, Constitution of Kenya, (2010).

Mugho MS, 'Causes of the recent teachers' strikes in Kenya' 2 Journal of Public Policy and Administration 2, 2017, 37.

$8 \quad$ Kenya Ferry Services Limited v Dock Workers Union (Ferry Branch) (2015) eKLR.

9 Polo R, Strengthening Kenya's Education Sector: A Focus on Teachers' Strike 2015, 2015, 5.

10 Country reports on Human rights practices for 2016 United States department of State, Kenya 2016 Human Rights report, 2016, 20.

(2015) eKLR.

12 Teachers Service Commission v Kenya National Union of Teachers \& another (2013) eKLR.
} 
in certain instances, the right to strike is in line with the best interest principle of the child.

There has hardly been investigation on how a balance between the teachers' right to strike and the children's right to education in Kenya can be attained. ${ }^{13}$ This is the research gap that this paper intends to fill in. To do this, Section II provides the theoretical framework that grounds the discussion at the centre of the paper. This framework is the theory of interests. Section III examines and provides an in-depth analysis on the current legal framework on both the teachers' right to strike and the children's right to education. It also looks at instances where there is a conflict between the two rights. Section IV attempts to find a legal balance between the teachers' right to strike and the children's right to education. This Section further looks into the challenges Kenyan courts face in interpreting the best interest of the child principle. It also highlights the challenges faced by the United States of America (USA) and South Africa when balancing these two rights. The USA and South Africa have been selected because both have faced similar challenges as Kenya when balancing these rights. Thus, they are suitable jurisdictions from which Kenya can borrow lessons in order establish a proper balancing approach. Section $\mathrm{V}$ concludes the paper as well as provides recommendations on balancing the two competing rights.

\section{The Theory of Interests}

With the enactment of the Universal Declaration of Human Rights in 1948, courts have perennially been faced with the challenge of balancing competing interests whenever a conflict arises between two or more human rights. ${ }^{14}$ These conflicts between various competing human rights led to the development of the theory of interests, a theory recognising the need to balance competing interests. However, it still appears that various jurisdictions, including Kenya, are still faced with the challenge of balancing competing interests such as the teachers' right to strike versus the children's right to education. ${ }^{15}$

13 Kimani S, 'Implementation of children's rights in Kenya: Legal, social and economic constraints', Academia.edu, 2013, 13.; Sihanya B, 'Devolution and education law and policy in Kenya' Kenya Human Rights Commission (KHRC) workshop on Devolution in Kenya at Palacina Hotel, Nairobi, 18 April 2013, 27: Odongo O G, 'The domestication of international standards on the rights of the child: A critical and comparative evaluation of the Kenyan example' 12 International Journal of Children's Rights 1, 2004, 422.

14 Brems E, Conflict between fundamental rights, Intersentia, Poland, 2008, 3.

15 Kenya National Commission on Human Rights, Making the Bill of Rights Operational: Policy, Legal and Administrative priorities and considerations, 2011, 31. 
The main advocates for the theory of interests are scholars from the sociological school of thought. One of its main proposers is Roscoe Pound. Pound defines an interest as a claim of a human being or group of human beings that he, she or group needs to satisfy and that a democratic society should take into account. ${ }^{16}$ He further expounds that in any society there are three main legal interests which include public, individual and societal interests. ${ }^{17}$ Pound defines the societal interests as the needs of a social group that must be satisfied. ${ }^{18} \mathrm{He}$ further defines public interests as the claims of a state, the political organisation of the society. ${ }^{19}$ The right to children's education is a public legal interest as it is a claim of the state whereas the right to teacher's strike is a societal interest because it is an interest of teachers who are an integral social group. In addition, Pound states that there are instances where conflicts arise between two competing societal interests. This is when two social groups are pursuing different ends and each end is in favour of one social group but disadvantages the other group. ${ }^{20}$ He further propounds that, whenever such a conflict arises, there is a general disposition for courts to rule in favour of the weightier interest. ${ }^{21}$ In instances where there are competing interests, Pound maintains, the state should provide a balance that will eliminate friction between these interests and will not harmfully affect the enjoyment of these interests. ${ }^{22}$ William James concurs with Pound and asserts that when the state is satisfying various interests, there should be a very minimal sacrifice of interests whenever a conflict arises. ${ }^{23}$ Rudolf Von Jhering also agrees with Pound and articulates that, where there is a conflict between interests, the state is required to employ strategies that will ensure a balance between such interests. ${ }^{24}$

There must therefore, be a balance whenever there is a discord between the teachers' right to strike and the children's right to education. Moreover, the courts should ensure that there is minimal sacrifice of interests, particularly the teachers' right to strike, whenever a clash ensues between these two fundamental rights.

16 McLean B E, 'Roscoe Pound's Theory on Interests and the furtherance of Western Civilization' 41 II Politico 1, 1976, 12.

17 McLean B E, 'Roscoe Pound's Theory on Interests and the furtherance of Western Civilization', 2.

18 Pound R, 'A survey of social interests' 57 Harvard Law Review 1, 1943, 2.

19 McLean B E, 'Roscoe Pound's Theory on Interests and the furtherance of Western Civilization' 41 II Politico 1, 1976, 16.

20 Benditt M T 'Law and the balancing of interests' 3 Social Theory and Practice 3, 1975, 328.

21 Pound R, An introduction to the philosophy of law, Yale University Press, New Haven, 1930, 45.

22 Pound R, 'A survey of social interests' 57 Harvard Law Review 1, 1943, 2.

23 Patterson W E 'Roscoe Pound on Jurisprudence’ 60 Columbia Law Review 8, 1960, 1128

24 Hampstead L, Introduction to Jurisprudence, $3^{\text {td }}$ ed, Stevens and Sons, London, 1972, 335. 
John Plamenatz builds on the view of Pound and Von Jhering. He propounds that, to balance competing interests, there may be a need to have a compromise. This compromise involves finding a solution that is acceptable to both parties. ${ }^{25}$ It is in this vein that Plamenatz provides that some people are of the notion that, when balancing competing interests, the weightier interest tends to be given more importance than the less weighty interest. ${ }^{26}$ This view point fails to consider the harm caused to the beneficiaries of the less weighty interest when the interests of these beneficiaries are limited.

Pound and Vincent Luizzi further provide that the laws drafted by legislators serve as a guide to determine which interests are to be recognised and the ones which are to prevail. The ones that are to prevail are often the interests considered to be more important than the others and they are dubbed the weightier interest. Further, courts are the ones tasked with balancing competing interests in line with the guidelines provided by the legislators. ${ }^{27}$

The Supreme Court of United States in Gillette $v$ United States provided that when balancing competing interests, courts can only favour one interest over the other in circumstances whereby limiting one societal interest will not adversely affect the party whose interests have been limited. ${ }^{28}$ The courts can also favour one interest in cases where there exist alternatives for the party whose interests have been limited. Such alternatives may be allowing the employees to strike for a few days as opposed to complete denial of the right to strike. ${ }^{29}$

However, in the Kenyan context of balancing the teachers' right to strike and the children's right to education, the Court of Appeal in Teachers Service Commission v Kenya National Union of Teachers \& 3 others limited the teachers' right to strike in a manner that adversely affects them as a societal group. ${ }^{30}$ The Court also failed to recognise that the teachers have no alternative mechanisms to attain their societal interest. The author will come back to this point.

In light of the above, one can fairly see that the theory of balancing competing interests alludes to the fact that, in instances where there is a conflict between rights, such as the right to strike and the right to education, a balance should be ensured so as to achieve a win-win situation for both parties.

\footnotetext{
Benditt M T 'Law and the balancing of interests' 3 Social Theory and Practice 3, 1975, 328.

Benditt M T 'Law and the balancing of interests', 329.

Luizzi V, 'Balancing of interests in courts' 20 Jurimetrics 4, 1980, 374

Gillette v United States (1971), The Supreme Court of the United States.

Bullock v Carter (1972), The Supreme Court of the United States.

(2015) eKLR.
} 


\section{Legal Framework}

This Section covers the legal framework of the question at the focal point of this paper. It analyses the legal framework governing the teachers' right to strike and the children's right to education in Kenya. It further highlights the various instances where the children's right to education conflicts with the teachers' right to strike in Kenya's legal framework.

\section{i. $\quad$ Right to Strike in Kenya}

\section{a. International Legal Framework}

The Constitution of Kenya provides that the general rules of international law and any treaty ratified by Kenya shall form part of the applicable legal framework of Kenya. ${ }^{31}$ The right to strike has been recognised in a number of international instruments such as the International Covenant on Economic, Social and Cultural rights, ${ }^{32}$ the International Covenant on Civil and Political rights $^{33}$ and the International Labour Organisation No 87, ${ }^{34}$ just to mention but a few.

Internationally, Kenya has ratified several treaties to regulate labour relations. One of these treaties is the Right to Organise and Collective Bargaining Convention, which provides employees with the right to employ strikes to safeguard their right to organise unions. ${ }^{35}$ Moreover, the Abolition of Forced Labour Convention prohibits using forced labour to punish employees such as teachers for using strikes to agitate for their pressing needs. ${ }^{36}$ Further, the Voluntary Conciliation and Arbitration Recommendation affirms that the provisions of this framework shall not limit the right to strike. ${ }^{37}$

\section{b. Domestic Legal Framework}

At the domestic level, the right to strike has been enshrined extensively in the Kenyan legal framework. Article 41 of the Constitution of Kenya provides

\footnotetext{
Article 2 (5) and (6), Constitution of Kenya (2010).

United Nations Human Rights Office of the High Commissioner, UN rights expert: Fundamental right to strike must be preserved, 2017, 1.

33 Article 8, International Covenant on Economic, Social and Cultural rights (1976).

34 Article 22, International Covenant on Civil and Political rights (1976).

35 Article 3, Right to Organise and Collective Bargaining Convention (No. 98 of 1949).

36 Article 1, The Abolition of Forced Labour Convention (No. 105 of 1957).

37 Para 7, Voluntary Conciliation and Arbitration Recommendation (No.92 of 1951).
} 
that every employee, including teachers, have the right to strike. ${ }^{38}$ During the teachers' strike of $2009,{ }^{39}$ teachers raised the issue of the infringement of their right to a just wage as provided for in the Constitution. ${ }^{40}$ The right to just wages is usually at the centre of the teachers' right to strike.

Further, Section 2 of the Kenyan Employment Act goes ahead to define a strike as a mechanism of pushing for dispute resolution by the employees. ${ }^{41}$ This definition has been reiterated in Section 2 of the Labour Relations Act. ${ }^{42}$ The Labour Relations Act provides that any person can engage in either a strike or a lockout. ${ }^{43}$ Teachers can only participate in a strike if they meet the three-step criterion outlined under the Labour Relations Act. ${ }^{44}$ The first step requires that the subject matter of a trade dispute should either concern their employment terms or trade union registration..$^{45}$ The second step requires that teachers can only engage in a strike if the employment dispute cannot be resolved either by means provided for under the law or under a registered collective agreement. ${ }^{46}$ The last step allows teachers to go on strike if they have given due notice of seven days to their employer and the Cabinet Secretary of Labour and Social Protection of their intention to go on strike. ${ }^{47}$

The Labour Relations Act also gives circumstances whereby strikes are prohibited. ${ }^{48}$ The first circumstance is if a law, court award or any collective agreement prohibits teachers from carrying out a strike. ${ }^{49}$ The second is if the subject matter of the strike is regulated by a particular collective agreement binding on both the teachers and their employer. ${ }^{50}$ The third circumstance refers to cases whereby the parties have agreed to using alternative dispute resolution mechanisms as opposed to going on strike. ${ }^{51}$

38 Article 41 2(d), Constitution of Kenya (2010).

39 Ogol O J and Chui M M, 'Critical analysis of influence of teacher management on learners' academic performance in public primary schools in Kenya' 5 International Journal of Education and Research 2 , 2017,32 .

40 Article 412 (a), Constitution of Kenya (2010).

41 Section 2, Employment Act (Act No.1 of 2007).

42 Section 2, Labour Relations Act (Act No. 14 of 2007).

43 Section 76, Labour Relations Act (Act No 14 of 2007).

44 Section 76, Labour Relations Act (Act No 14 of 2007).

45 Section 76 (a), Labour Relations Act (Act No 14 of 2007).

46 Section 76 (b), Labour Relations Act (Act No 14 of 2007).

47 Section 76 (c), Labour Relations Act (Act No 14 of 2007).

48 Section 78, Labour Relations Act (Act No 14 of 2007).

49 Section 78 1(a), Labour Relations Act (Act No 14 of 2007).

50 Section 78 1(b), Labour Relations Act (Act No 14 of 2007).

51 Section 78 1(c), Labour Relations Act (Act No 14 of 2007). 
Moreover, strikes are prohibited if the employers and employees are engaged in an essential service. ${ }^{52}$ An essential service is any service that, if interrupted, will most likely endanger the life of the population. ${ }^{53}$ However, teachers do not provide essential services. Thus, their right to strike cannot be limited on these grounds. $^{54}$

\section{ii. Children's Right to Education in Kenya \\ a. International Legal Framework}

The children's right to education is enshrined in various conventions that Kenya has ratified at both the regional and international levels. At the regional level, the African Charter on the Rights and the Welfare of the Child affirms that countries shall maintain appropriate mechanisms to fulfil the realisation of the children's right to education within their states. ${ }^{55}$

At the international level, the United Nations Convention on the Rights of the Child imposes on states parties the duty to respect and promote the children's right to education. ${ }^{56}$ The Convention also requires states to ensure that children enjoy equitable opportunities to access education..$^{57}$ Moreover, it encourages states to co-operate in matters relating to education so as to allow every child to enjoy this right. ${ }^{58}$ In addition, the Convention affirms that the best interest principle of the child shall be the primary consideration for any authorities carrying out any acts that may affect the rights of the child. ${ }^{59}$

\section{b. Domestic Legal Framework}

The Constitution of Kenya affirms that every child has the right to a free and mandatory education. ${ }^{60}$ Section 2 of the Children Act defines education as the giving of intellectual, moral, spiritual training and any other training to a child. ${ }^{61}$

\footnotetext{
Section 78 1(f), Labour Relations Act (Act No 14 of 2007).

Section 81, Labour Relations Act (Act No 14 of 2007).

Fourth Schedule, Labour Relations Act (Act No. 14 of 2007).

Article 11 (3), African Charter on the Rights and Welfare of the Child (1990).

Article 28, Convention on the Rights of the Child (1990).

Article 28 1(c), Convention on the Rights of the Child (1990).

Article 28 (3), Convention on the Rights of the Child (1990).

Article 4, African Charter on the Rights and Welfare of the Child (1990); Article 3, Convention on the Rights of the Child (1990).

60 Article 53 1(b), Constitution of Kenya (2010).

61 Section 2, Children's Act (No 8 of 2001).
} 
This Act states that it is the State and children's parents that have an obligation to respect the right to education of children. ${ }^{62}$

Section 28 of the Basic Education Act provides that the Cabinet Secretary of Education shall ensure that children have access to education. ${ }^{63}$ The Cabinet Secretary for Education shall further necessitate the achievement of this right by governing the establishment of public schools. ${ }^{64} \mathrm{He}$ or she is also mandated to ensure that special and integrated schools are established for children living with disabilities in Kenya. ${ }^{65}$ The Basic Education Act further affirms that the State must ensure that the schools are adequately staffed and have adequate financial resources ${ }^{66}$ Moreover, one of the guiding principles of the National Child Protection System Framework is that it is of utmost significance to ensure children's protection by protecting their essential rights such as their right to education. ${ }^{67}$

Article 53 of the Constitution provides that the best interest of the child is paramount for any matter concerning the child. ${ }^{68}$ The Basic Education Act reiterates this best interest principle in its Section 58 where it gives the Management Committees of pre-primary institutions and the Board of Management of schools the mandate to respect and promote the best interest of the child. ${ }^{69}$ Section 4 of the Children Act further avers that for any action to be taken by any institution or body, the best interest of the child must be given paramount consideration. ${ }^{70}$ The Children Act alludes also to the fact that institutions and courts of law must always safeguard, promote and conserve children's education and welfare in light of the best interest of the child principle. ${ }^{71}$ However, there is no law in Kenya that does define or provide guidelines on what amounts to the best interest of the child so as to properly weigh the children's right to education and the teachers' right to strike. ${ }^{72}$

\footnotetext{
Section 7, Children's Act (No.8 of 2001).

Section 28 (1), Basic Education Act (No 14 of 2013).

Section 28 (2), Basic Education Act (No 14 of 2013).

Section 28 (2)(d), Basic Education Act (No 14 of 2013).

Section 39, Basic Education Act (No 14 of 2013).

67 National Council for Children's Services, The Framework. for the National Child Protection System for Kenya, 2011, 10.

68 Article 53 (2), Constitution of Kenya (2010).

69 Section 59 (a), Basic Education Act (No 14 of 2013).

70 Section 4 (2), Children's Act (No 8 of 2001).

71 Section 4 (3), Children's Act (No 8 of 2001).

72 See for instance Teachers Service Commission v Kenya National Union of Teachers \& 3 others (2015) eKLR, Article 53 (2), Constitution of Kenya (2010) and Section 4, Children's Act (No 8 of 2001).
} 


\section{Conflict between the Teachers' Right to Strike and Children's Right to Education in Kenya}

Looking at the legal framework on the right to education and that on the right to strike, one may conclude that there is indeed a conflict. This is because the Constitution and Acts of Parliament are not clear on which of the two rights takes precedence over the other. ${ }^{73} \mathrm{~A}$ pertinent question that arises whenever this conflict occurs is whether the legal framework provides instances where one right can be deemed to supersede the other. This Section of the paper highlights how the Kenyan courts, particularly the Employment and Labour Relations Court and the Court of Appeal, have addressed this conflict.

According to the Constitution of Kenya, both the teachers' right to strike and children's right to education are not absolute. ${ }^{74}$ They can be limited as per the confines of the law outlined in Article 24 of the Constitution of Kenya. ${ }^{75}$

In Teachers Service Commission v Kenya National Union of Teachers \& 3 others, the applicants petitioned the Employment and Labour Relations Court in 2015 to issue an injunction to prevent the teachers from exercising their right to strike. The applicants informed the court that the teachers' nationwide strike would paralyse the education system in the nation. The Court issued an injunction, which prevented teachers from exercising their right to strike. It further acknowledged Article 24 on limitation of rights. However, it simply stated that since the teachers' strike was prejudicing the children's right to education, they had to issue an injunction. ${ }^{76}$

The case proceeded to the Court of Appeal in 2015. The Court of Appeal did not reverse the injunction issued by the Employment and Labour Relations Court. ${ }^{77}$ By the Court of Appeal retaining the decision of the Employment and Labour Relations Court, it seemed to imply that the children's right to education is more fundamental than the teacher's right to strike.

Similarly, in Teachers Service Commission v Kenya National Union of Teachers, Ministry of Labour and Social Protection (Interested party), a 2019 case, the Employment and Labour Relations Court limited again the teachers' right to strike as it provided that the children's right to education is more fundamental by virtue

Article 24, Constitution of Kenya (2010); Section 4, Children's Act (No 8 of 2001).

Article 24, Constitution of Kenya (2010).

Article 24, Constitution of Kenya (2010).

(2015) eKLR.

TSC v KNUT \& 3 others (2015) eKLR. 
of the best interest of the child principle. ${ }^{78}$ The Court, on balancing these two rights as per Article 24 of the Constitution, issued an injunction on the grounds that the teachers' strike would paralyse learning. ${ }^{79}$ Moreover, the Court stated, the strike would violate the access to free, basic and compulsory education in all public schools. And, this would amount to a gross violation of Article 53 of the Constitution, which is on the best interest of the child. ${ }^{80}$

Both the Employment and Labour Relations Court and the Court of Appeal have mentioned Article 24 of the Constitution of Kenya, which is the overarching law on limitation of human rights. The Courts, however, on applying Article 24 of the Constitution on limitation of rights, were always limiting the teachers' right to strike on account of the best interest of the child principle. But the Courts were not analysing whether limiting the teacher's right to strike by issuing injunctions is the least restrictive means. ${ }^{81}$ Moreover, a fundamental question arises as to whether the best interest of the child principle connotes that the children's right to education should be held superior to the teachers' right to education. The Constitution, Acts of Parliament and case law discussed in this paper do not explicitly aver that this principle allows authorities in making determinations concerning the children's right to education to always allow this right to trump over any right it is in conflict with.

Many scholars have discussed the best interest principle of the child and provided that there is a challenge in the interpretation of this principle. ${ }^{82}$ Kenyan scholars such as Ben Sihanya, Godfrey Odongo and Samuel Kimani have affirmed the application of the best interest principle of the child for matters touching directly on children's rights.$^{83}$ However, these three scholars

\footnotetext{
(2019) eKLR.

(2019) eKLR.

(2019) eKLR.
}

${ }^{81}$ TSC v KNUT \& 3 others (2015) eKLR; Teachers Service Commission v Kenya National Union of Teachers, Ministry of Labour and Social Protection (Interested party) (2019) eKLR.

82 Mnookin R, In the interest of cbildren: Advocacy, Law Reform and Public Policy, Program on Negotiation, Cambridge, 1985, 17.; Odongo O G, 'The domestication of international standards on the rights of the child: A critical and comparative evaluation of the Kenyan example' 12 International Journal of Children's Rights 1, 2004, 422. ; Alston P, 'The best interest principle: towards a reconciliation of culture and human rights, reconciling culture and human rights' 8 International Journal of Law, Policy and the Family 1, 1994, 4.

83 Kimani S, 'Implementation of children's rights in Kenya: Legal, social and economic constraints', Academia.edu, 2013, 13.; Sihanya B, 'Devolution and education law and policy in Kenya' Kenya Human Rights Commission (KHRC) workshop on Devolution in Kenya at Palacina Hotel, Nairobi, 18 April 2013, 27: Odongo O G, 'The domestication of international standards on the rights of the child: A critical and comparative evaluation of the Kenyan example' 12 International Journal of Children's Rights 1, 2004, 422. 
and many others are silent on the challenges in the interpretation of this principle. $^{84}$

Philip Alston states that in Australia the Convention on the Rights of the Child does not explicitly define what amounts to the best interest of the child principle and this leaves the courts with the task of grappling with this concept. ${ }^{85}$ The Australian Human Rights Commission further affirmed this and provided that the best interest principle is subjective and its interpretation and application are discretionary. ${ }^{86}$

The Committee on the Rights of Children in General Comment No 14 further provides that, when any of the children's rights conflicts with another right, the courts should balance the two interests against each other and find a suitable compromise. ${ }^{87}$ The Committee also affirms that the concept 'best interest' is a complex one. As such, it should be dealt with on a case-by-case basis. ${ }^{88}$ Kenyan courts should thus employ this approach provided for by the Committee on the Rights of Children as opposed to employing an absolutist approach whenever there is a conflict between the teachers' right to strike and the children's right to education.

In order for children to have access to quality education, teachers need to be motivated and paid well. ${ }^{89}$ Strikes are therefore essential as during teachers strike teachers agitate the state for better pay and ensure that children have access to quality education. ${ }^{90}$ The right to strike is thus actually exercised in the best interest of the child as the teachers' during the 2011 and 2012 strikes were agitating the state to resolve understaffing in a bid to ensure that students enjoy quality education. ${ }^{91}$ The Employment and Labour Relations Court and the Court

84 Kimani S, 'Implementation of children's rights in Kenya: Legal, social and economic constraints', 13.; Sihanya B, 'Devolution and education law and policy in Kenya' Kenya Human Rights Commission (KHRC) workshop on Devolution in Kenya at Palacina Hotel, Nairobi, 18 April 2013, 27: Odongo $\mathrm{O} G$, 'The domestication of international standards on the rights of the child: A critical and comparative evaluation of the Kenyan example', 422.

85 Australian Human Rights Commission, Human Rights Brief No.1, 1999.

86 Alston P, 'The best interest principle: towards a reconciliation of culture and human rights, reconciling culture and human rights' 8 International Journal of Law, Policy and the Family 1, 1994, 4.

87 Committee on the Rights of the Children, General Comment No.14 on the right of the child to bave his or ber best interest taken as primary consideration, 29 May 2013, 10.

88 Committee on the Rights of the Children, General Comment No.14 on the right of the child to have bis or her best interest taken as primary consideration, 29 May 2013, 9.

89 Jonyo O D and Jonyo O B, 'Teacher Management: Emerging Issues in Kenya' 4 European Journal of Educational Sciences 1, 2017, 35.

90 Jonyo O D and Jonyo O B, 'Teacher Management: Emerging Issues in Kenya', 35.

91 Munene A, 'The Right to strike-sustainable constitutional reform: Comparative case studies of workers' strikes in the Kenyan public sector' 37 Hastings International and Comparative Law Review 1, 2014,163 . 
of Appeal in Kenya should not have been therefore quick to issue injunctions to bar teachers from exercising their right to strike.

The purpose of the courts as provided by Article 1592 (a) of the Constitution of Kenya is to ensure justice, which entails giving to each one what is constitutionally due to them. ${ }^{92}$ Moreover, the Basic Education Act in Section 39 requires the State to ensure that schools are adequately staffed and given the resources they require. ${ }^{93}$ Several complaints during teachers' strikes are in respect to being understaffed and with respect to being underpaid. ${ }^{94}$ If teachers are understaffed and underpaid, they may be unable to provide education services that are in the best interest of the child. Teachers should therefore be allowed to strike to be able to agitate the State to respect its duty towards teachers and ensure that children are able to be provided with education services that are in their best interest.

Further, even if teachers can use alternative dispute resolution mechanisms such as arbitration, mediation and conciliation to resolve their disputes with the State, they are still not as effective as the use of strikes. Arbitration is an employment dispute resolution mechanism whereby a third neutral party called 'arbitrator' is appointed by the parties to determine the dispute and give a final and binding award..$^{95}$ Arbitration is an ideal dispute resolution mechanism whereby the parties to a conflict have equal bargaining power. ${ }^{96}$ In the employment disputes, employees such as teachers usually do not have the same bargaining power as their employer (mostly the State), making strikes an ideal dispute resolution mechanism. Arbitration is therefore not the most suitable dispute resolution mechanism for teachers.

With respect to the challenges of mediation, scholars such as Kariuki Muigua acknowledge that, in mediation, power imbalances in the process may cause one party to have the upper hand, hence causing the outcome to unfavourably address

\footnotetext{
Article 159 2(a), Constitution of Kenya (2010).

Section 39, Basic Education Act (No.14 of 2013).

94 Polo R, Strengthening Kenya's Education Sector: A Focus on Teachers' Strike 2015, 2015, 4-5; Jonyo O D and Jonyo O B, 'Teacher Management: Emerging Issues in Kenya' 4 European Journal of Educational Sciences 1, 2017, 34-35.

95 Muigua K, 'ADR: The Road to Justice in Kenya', Chartered Institute of Arbitrators-Kenya Branch, International Arbitration Conference at Sarova Whitesands Hotel, Mombasa Kenya, 7 and 8 August $2014,31$.

96 Muigua K, 'ADR: The Road to Justice in Kenya', Chartered Institute of Arbitrators-Kenya Branch, International Arbitration Conference at Sarova Whitesands Hotel, Mombasa Kenya, 7 and 8 August 2014,32 .
} 
the concerns and interests of the other party. ${ }^{97}$ In the same vein, John Cooley affirms that, for mediation, the mediator has no power to impose the settlement. It is not binding on the parties and lacks enforceability. ${ }^{98}$ These challenges clearly indicate why mediation is not an effective dispute resolution mechanism for teachers to agitate for their pertinent needs.

Section 10 of the Labour Relations Act provides for conciliation as a dispute resolution mechanism for employment disputes. ${ }^{99}$ Conciliation is a dispute resolution mechanism whereby the neutral party takes more of an interventionist role to help the parties to a conflict to get to a resolution. ${ }^{100}$ Muigua provides that, for this method, the conciliator does not have the power to impose a settlement. His or her role is more advisory than determinative. ${ }^{101}$ This poses a challenge to resolve teachers' employment disputes since the settlement is not binding on the parties.

However, in a bid to make mediation more effective, the judiciary of Kenya has provided that for court annexed mediation, the mediation settlement can be registered by a court and enforced as a court order. ${ }^{102}$ This still poses a challenge where there is a conflict between the teachers' right to strike and the children's right to education. It does not resolve the power imbalances between the teachers and the state during mediation.

Strikes are therefore the most suitable dispute resolution mechanisms as they unlock an impasse in the collective bargaining and negotiation process. The nature of strikes is further fundamental to the whole institution of collective bargaining. ${ }^{103}$

${ }^{97}$ Muigua K, 'ADR: The Road to Justice in Kenya', Chartered Institute of Arbitrators-Kenya Branch, International Arbitration Conference at Sarova Whitesands Hotel, Mombasa Kenya, 7 and 8 August 2014, 29.

98 Cooley J, Mediation Advocacy, 2 ed, National Institute for Trial Advocacy, Notre Dame, 2002,6.

99 Section 10, Labour Relations Act (Act No 14 of 2007).

100 Muigua K, 'ADR: The Road to Justice in Kenya', Chartered Institute of Arbitrators-Kenya Branch, International Arbitration Conference at Sarova Whitesands Hotel, Mombasa Kenya, 7 and 8 August 2014, 30 .

101 Muigua K, 'ADR: The Road to Justice in Kenya', Chartered Institute of Arbitrators-Kenya Branch, International Arbitration Conference at Sarova Whitesands Hotel, Mombasa Kenya, 7 and 8 August 2014, 30 .

102 The Judiciary, Court Annexed Mediation, 2016, 3.

103 Universities Academic Staff Union v Maseno University (2013) eKLR. 


\section{Balancing competing Interests: The Teachers' Right to Strike vs Children's Right to Education}

From the previous Section, there is indeed a conflict between the teachers' right to strike and the children's right to education. The courts usually rely on the best interest principle of the child to limit the teachers' right to strike. ${ }^{104}$ There is a need to look into the challenges of interpreting the best interest principle of the child. Therefore, there is an imminent need to study various balancing approaches that can be used whenever a conflict between the two rights at the centre of this paper occurs. This Section of the paper thus covers the challenges in interpretation of the best interest principle of the child. It further studies the various balancing approaches that the courts can apply whenever a conflict between the teachers' right to strike and the right to children's education occurs.

\section{i. Challenges in Interpretation of the Best Interest Principle of the Child}

In instances whereby a conflict arises between the teachers' right to strike and the children's right to education, courts are faced with the task of balancing these competing interests. Thus far, the courts in Kenya have resorted to relying on the best interest principle of the child whenever they are tasked with balancing these two competing rights.

In Teachers Service Commission v Kenya National Union of Teachers \& 3 others, where the children's right to education was in conflict with the teacher's right to strike, the Court of Appeal did not expressly define what amounts to the best interest of the child principle. ${ }^{105}$ Professor Sihanya, on analysing the stance taken by courts whenever a conflict arises between the teachers' right to strike and children's right to education, affirms that the courts still suppress the main means that teachers have to bargain for their fundamental needs. ${ }^{106}$

The challenges in the interpretation of the best interest principle of the child have been raised by various scholars. Aron Degol, an Ethiopian scholar, and James Himes, an American scholar, observe that one of the challenges is that the Convention on the Rights of the Child does not define the best interest

\footnotetext{
104 Jarso F J 'Implementing the children's right agenda in Kenya: Taking stock of the progress, hurdles and prospects' 27 American University International Law Review 3, 2012, 692.

105 (2015) eKLR.

106 Sihanya B, 'Public participation and public interest lawyering under the Kenyan Constitution: Theory, process and reforms ' 9 Law Society of Kenya Journal 1, 2013, 7.
} 
principle. ${ }^{107}$ Robert Mnookin builds on this observation to allude to the fact that the Convention on the Rights of the Child does not also provide a set of guidelines to be followed by the courts when determining what amounts to the best interest of the child. ${ }^{108}$ This lack of guidelines leads courts to make subjective decisions on what elements must be considered when deciding what amounts to the best interest of the child. ${ }^{109}$ Other scholars such as John Elster affirm that the best interest principle is obscure in nature. ${ }^{110}$ There also exist guidelines on this principle that were developed by Yvette Brown and Kimberley Jolson. However, these guidelines have limited application in that they can only be applied to custody cases. ${ }^{111}$

Still in this vein, the Commissioner for Human Rights Council of Europe provides that what amounts to the best interest principle of the child differs from one country to another based on the level of development. ${ }^{112}$ Furthermore, in a bid to resolve this challenge of lack of guidelines for the best interest principle of the child, the United Nations High Commissioner for Refugees (UNCHR) in 2018 drafted guidelines on assessing and determining the best interest of the child. ${ }^{113}$ However, these guidelines only apply to refugee child protection cases. ${ }^{114}$ They cannot therefore be applied to cases of conflict between the teachers' right to strike and the right to children's education.

In Kenya, the Court of Appeal, being the highest court to have adjudicated on the matter, seems to have taken an absolutist approach when resolving the conflict between the teachers' right to strike and the children's right to education. This is because it is quick to issue an injunction to prevent teachers from exercising their right to strike while relying on the best interest principle. ${ }^{115}$ This raises a

107 Degol A and Dinku S 'Notes on the principle "Best interest of the child": Meaning, history and its place under Ethiopian Law' 5 Mizan Law Review 2, 2011, 324.

108 Mnookin R, 'Child custody adjudication: Judicial functions in the face of indeterminacy' 39 Law and Contemporary Problems 3, 1975, 260.

109 Skivens M, 'Judging the child's best interests: Rational reasoning or subjective presumptions' 53 Acta Sociologica 4, 2010, 339.

110 Elster J, Solomonic judgments: Studies in the limitation of rationality, Cambridge University Press, Cambridge, $1989,5$.

111 Brown M Y and Jolson A K, 'Chief Justice O’Connor juvenile justice jurisprudence: A consistent approach to inconsistent interests' 48 Akron Law Review 1, 2015, 67.

112 Commissioner for Human Rights Council of Europe, The principle of the best interest of the child what it means and what it demands from adults, 2008,4.

113 UN High Commissioner for Refugees, Guidelines on assessing and determining the best interests of the child, 2018, 10.

114 UN High Commissioner for Refugees, Guidelines on assessing and determining the best interests of the child, 2018, 17.

115 Teachers Service Commission v Kenya National Union of Teachers \& 3 others (2015) eKLR. 
fundamental concern as there are no determined values which clearly outline what amounts to the best interest of the child in Kenya's legal framework. ${ }^{116}$

It is worth noting that the UNHCR guidelines heavily borrow from General Comment 14 of the Committee on the Rights of the Children. General Comment 14 does not define the best interest principle of the child. ${ }^{117}$ It just provides that the best interest principle is a substantive right, a fundamental interpretive legal principle and a rule of procedure. ${ }^{118}$ The Comment further provides that the concept of the best interest principle of the child is complex and should be dealt with on a case-by-case basis. ${ }^{119}$ Along these lines, it provides that, for cases whereby the children's right conflicts with another right, the two rights should be balanced and a suitable compromise reached. ${ }^{120}$ This viewpoint by the Committee on the Rights of the Children is what should be employed in a jurisdiction such as Kenya.

From the evidence above, it is thus clear to affirm that there are indeed challenges in interpreting the best interest of the child principle. Furthermore, there are no defined guidelines or factors on what amounts to the best interest of the child in the various laws such as the Convention on the Rights of the Child ${ }^{121}$ and the African Charter on the Rights and Welfare of the Child, ${ }^{122}$ which Kenya has ratified and is bound to as per Articles 2(5) and 2(6) of the Constitution. ${ }^{123}$ Kenyan courts therefore face a challenge in determining which right to rule in favour of when deciding cases where the children's right to education conflicts with other rights such as the teachers' right to strike. There is then an urgent need to look into the possible balancing approaches that can be employed whenever there is a conflict between the teachers' right to strike and the children's right to education.

116 TSC v KNUT \& another (2012) eKLR; TSC v KNUT \& 2 others (2012) eKLR; TSC v KNUT \& 3 others (2015) eKLR, Teachers Service Commission v Kenya National Union of Teachers, Ministry of Labour and Social Protection (Interested party) (2019) eKLR.

117 Committee on the Rights of the Children, General Comment No.14 on the right of the child to have bis or her best interest taken as primary consideration, 29 May 2013, 3.

118 Committee on the Rights of the Children, General Comment No.14 on the right of the child to have his or her best interest taken as primary consideration, 29 May 2013, 4.

119 Committee on the Rights of the Children, General Comment No.14 on the right of the child to bave his or her best interest taken as primary consideration, 29 May 2013, 9.

120 Committee on the Rights of the Children, General Comment No.14 on the right of the child to have his or ber best interest taken as primary consideration, 29 May 2013, 10.

121 Article 3, Convention on the Rights of the Child (1990).

122 Article 4, African Charter on the Rights and Welfare of the Child (1990).

123 Article 2(5), Constitution of Kenya, (2010) 


\section{ii. Balancing Approaches}

To resolve the conflict between the teachers' right to strike and the right to children's education, courts in Kenya, the USA, and South Africa tend to employ three balancing approaches. The first approach is whereby the weightier interest always prevails whenever there is a conflict between the two rights. ${ }^{124}$ The second is the minimum core service approach. And the third is the balancing competing interests' approach whereby states try to balance the two competing interests whenever a conflict arises between the teachers' right to strike and children's right to education. ${ }^{125}$ These approaches are discussed below.

\section{a. The 'weightier interest prevails' approach}

This approach provides that, whenever two interests such as the teachers' right to strike and the children's right to education are in conflict, the weightier interest shall prevail. ${ }^{126}$ The courts in this approach usually compare the two competing interests so as to determine which interest is weightier.

In instances whereby there has been a conflict between the teachers' right to strike and the children's right to education, countries such as Kenya, through the Court of Appeal and the USA, through the supreme courts of a number of states, have deemed the children's right to education as weightier than the teachers' right to strike by virtue of the best interest of the child principle. ${ }^{127}$ Kenyan and USA courts have therefore resorted to granting injunctions whenever these two rights are in conflict. ${ }^{128}$

In the USA, in School Committee of the Town of Westerley $v$ Westerley Teachers Association, the teachers in Westerley went on strike because they were not being paid just wages. The Supreme Court of Rhodes Island in this case issued an injunction requiring the teachers to end their strike and return to their respective schools immediately. Moreover, the Court affirmed that the teachers were

124 Muñoz P C, 'Should education be designed as an essential service' ALACIP Conference, Montevideo, 27 July 2017, 2.

125 Tangwe N M, Tanga T P and Tanyi L P, 'Teachers' strikes and the right of learners to education: A critical literature review’ Academia.edu, 2015, 240.

126 Luizzi V, 'Balancing of interests in courts' 20 Jurimetrics 4, 1980, 378.

127 Teachers Service Commission v Kenya National Union of Teachers \& 3 others (2015) eKLR; Jefferson County Board of Education v Jefferson County Education Associaton (1990), Supreme Court of Appeals of West Virginia.

128 Pinellas County Classroom Teachers Association v Board Public Instruction Pinellas County (1968), Florida Supreme Court. 
going against the best interest of the child principle. This is because their strike prevented the children from exercising their right to education. ${ }^{129}$

The Supreme Court of Appeals of West Virginia, in Jefferson County Board of Education v Jefferson County Education Associaton, also stated that teachers' strikes are detrimental to the public welfare and the welfare of the students. ${ }^{130}$ In addition, the Benton County Superior Court issued an injunction that put an end to the Kennewick teachers' strike, which was affecting the children's education in Kennewick district. ${ }^{131}$ The USA therefore upholds the 'weightier interest prevails' approach as they have constantly ruled in favour of the children's right to education to the detriment of the teachers' right to strike.

Scholars such as Horsten and Le Grange advocate for education to be regarded as an essential service. They provide that lack of education could cause deleterious effects to the population. ${ }^{132}$ MacFarlane builds on Horsten's viewpoint and affirms that teachers' strikes limit the right to education of students which causes them to miss classes. He propounds that, as a result of teachers missing classes, students' access to future opportunities is negatively affected. Thus, this may harm the students and their families who are part of the population. ${ }^{133}$

Strikes have also been seen to cause short-term negative impacts on the students. For instance, strikes lead to a rise in the number of students retaking classes. ${ }^{134}$ This is because their performances had plummeted due to the frequency of the teachers' strikes. ${ }^{135}$ Thus, teachers' strikes cause both grave short-term and long-term harm to the population. In a bid to avoid this harm, some jurisdictions have pressed for education to be deemed an essential service. ${ }^{136}$

129 School Committee of the Town of Westerley v Westerley Teachers Association (1973), Supreme Court of Rhodes Island.

130 Jefferson County Board of Education v Jefferson County Education Associaton (1990), Supreme Court of Appeals of West Virginia.

131 Probert C, 'It is done! Kennewick teachers, administrators reach tentative agreement to end strike' Tri-City Herald, 29 August 2019, https://www.tri-cityherald.com/news/local/education/ article234536177.html on 10 November 2019.

132 Horsten D, 'The limitation of the educator's right to strike by the child's right to basic education' 27 Southern African Public Law 2, 2012, 521.

133 MacFarlane L J, The Right to Strike, Penguin Books, London, 1981, 140.

134 Belot M and Webbink D 'Do teachers strikes harm educational attainment of students' 24 Labour 4, 2010, 393.

135 Johnson D R, 'Do strikes and work- to-rule campaigns change elementary schools assessment results' 37 Canadian Public Policy 4, 2011, 482.

136 Muñoz P C, 'Essential Services, worker's freedom and distributive justice' 40 Social Theory and Practice 4, 2014, 661 . 
An essential service is any service that, if interrupted, would harm the population. ${ }^{137}$ Employees providing essential services are only allowed limited exercise of their right to strike. ${ }^{138}$ This is because of the potential adverse effects that these employees' strikes would have on the population. ${ }^{139}$ By declaring education as an essential service, the teachers' right to strike is limited and teachers are encouraged to use alternative dispute resolution mechanisms such as mediation. ${ }^{140}$ However, in Kenya, education does not fall under the list of essential services as provided for in the Fourth Schedule of the Labour Relations Act. ${ }^{141}$ The courts in Kenya cannot rely on this argument when limiting the teacher's right to strike.

The main advantage of the 'weightier interest' approach is that it ensures that the students' interest is considered. However, this approach is disadvantageous as it limits the teachers' right to strike. This leaves the teachers with hardly any appropriate means to agitate the State for their fundamental needs. Thus, in cases whereby there is a clash between the teachers' right to strike and the children's right to education, the courts in following this approach will always rule in favour of the children's right to education. There is therefore a need to look for an alternative approach to ensure a balance between the competing interests.

\section{b. The minimum core service approach}

In a bid to refine this 'weightier interest' approach, the 'minimum core service approach has been introduced for essential services in jurisdictions such as South Africa. ${ }^{142}$ The minimum core service approach, expounded by the International Labour Organisation in 2018 in its Freedom of Association Report, gives leeway for employees of essential services to exercise their right to strike. However, it requires them to still meet the basic needs of the users of their services during their strikes. ${ }^{143}$ This approach would allow teachers to exercise their right to strike as they still uphold the children's right to education. It could

137 Gernigon B, Odero A and Guido H, 'ILO principles concerning the right to strike' 137 International Labour Review 4, 1998, 20.

138 Section 81, Labour Relations Act (Act No. 14 of 2007).

139 Muñoz P C, 'Essential Services, worker's freedom and distributive justice' 40 Social Theory and Practice 4, 2014, 649 .

140 Horsten D, 'The limitation of the educator's right to strike by the child's right to basic education' 27 Southern African Public Law 2, 2012, 524.

141 Fourth Schedule, Labour Relations Act (Act No. 14 of 2007).

142 Section 72, Labour Relations Act (South Africa).

143 International Labour Organization, Freedom of Association: Compilation of decisions of the committee on Freedom of Association, 2018, 164. 
thus potentially assist in balancing the competing rights. It would allow for both teachers to exercise their right to strike and students to exercise their right to education if education is to be taken as a basic need or an essential service.

States that have made education an essential service should therefore apply the minimum core service approach, which leans towards balancing the two competing interests. Kenya, however, is not one of the states that have declared education an essential service. ${ }^{144}$ The country has attempted to introduce this minimum core service approach for essential services through the proposed Labour Amendment Bill that was tabled in Parliament in March 2019. This Bill attempted to amend Section 81 of the Labour Relations Act to allow employees whose work touches on essential services to participate in strikes for a period of five days. ${ }^{145}$ The Bill did this by expressly providing for a time period of 5 days, which was condemned in the past by the Committee of Experts at the International Labour Organisation. ${ }^{46}$ Therefore, Parliament needs to re-evaluate its viewpoint on the minimum core service approach before attempting to amend the existing provision on essential services in the Labour Relations Act.

\section{c. The balancing competing interests approach (the balancing approach)}

This balancing approach requires the courts to balance the teachers' right to strike over children's right to education when these two are in conflict. This approach stems from the balancing competing interests theory that has been propounded by various renowned scholars from the sociological school of the thought in the 1970s such as Pound and Von Jhering. ${ }^{147}$

This approach requires courts not to rank the competing societal interests when deciding cases regarding the two competing rights. Rather, it requires courts to look into the interests and balance them against each other. Moreover, this approach advocates that courts find a semblance of a balance whenever two rights such as the teachers' right to strike and the children's right to education are in conflict. ${ }^{148}$ In some states such as South Africa, the Constitutional Court,

\footnotetext{
144 Fourth Schedule, Labour Relations Act (Act No. 14 of 2007).

145 https://kenyaemploymentlaw.com/2019/07/29/new-bill-alert-those-in-essential-services-tostrike-for-only-5-days/ on 4 April 2020.

146 https://kenyaemploymentlaw.com/2019/07/29/new-bill-alert-those-in-essential-services-tostrike-for-only-5-days/ on 4 April 2020.

147 Benditt M T 'Law and the balancing of interests' 3 Social Theory and Practice 3, 1975, 328.

148 Port Elizabeth Municipality v Various Occupiers, (2004), Constitutional Court of South Africa.
} 
in the case of Port Elizabeth Municipality v Various Occupiers, has advocated for the balancing of competing interests whenever human rights are in conflict. ${ }^{149}$

Further, despite the fact that some states in the USA have applied a 'weightier interest' approach, there are still some states whose courts apply the balancing competing interests' approach whenever there is a conflict between two human rights. Further, the USA Supreme Court, in Pickering $v$ Board of Education, provided that where there is a clash between two rights in a state, it should undertake measures to ensure a balance between these two rights. ${ }^{150}$

The Committee on the Rights of Children in General Comment No 14 further advocated for this approach in dealing with conflicts that arise between children's rights and other rights. ${ }^{151}$

It is important to emphasise that, whenever there is a conflict between two competing interests and the courts need to limit one right, they should do so using the least restrictive means. ${ }^{152}$ This raises an integral question as to whether the issuing of injunctions by the courts to prevent teachers from exercising their right to strike constitutes the least restrictive means. This is because when the courts issue injunctions they leave teachers with limited or no mechanisms to be able to advocate for their basic needs such as increase in wages from the State.

Pound, through the balancing competing interests' theory, which this approach is anchored on, propounds that, if there are competing rights, the courts should maintain a balance that will remove friction between these rights and not adversely affect their enjoyment. ${ }^{153}$ Thus, in cases whereby there is a conflict between the teachers' right to strike and the children's right to education, the courts in Kenya should determine the cases on a case-by-case-basis approach. This would entail considering all circumstances surrounding each case to ensure that the interests of both teachers and the children are met.

Pound affirms that the purpose of law is to meet and advance the interests of the society it serves. ${ }^{154}$ The balancing competing interests' approach ensures that law serves this purpose as it urges the courts to ensure that both the

\footnotetext{
Port Elizabeth Municipality v Various Occupiers, (2004), Constitutional Court of South Africa.

Pickering v Board of Education (1968), Supreme Court of the United States.

151 Committee on the Rights of the Children, General Comment No.14 on the right of the child to have his or her best interest taken as primary consideration, 29 May 2013, 10.

152 Patterson W E 'Roscoe Pound on Jurisprudence’ 60 Columbia Law Review 8, 1960, 1128.

153 Pound R, 'A survey of social interests' 57 Harvard Law Review 1, 1943, 2.

154 Nabaldian E, 'Introductory Concepts on Sociological Jurisprudence: Jhering, Durkheim, Ehrlich’ 4 Mizan Law Review 2, 2010, 351.
} 
teachers' right to strike and the children's right to education are respected and upheld. Plamenatz builds on Pound's view and provides that, when the courts are balancing competing interests, they may sometimes have to find a middle ground. This middle ground may help them find a solution which is acceptable to both social groups. This compromise enables the two conflicting social groups to reconcile the differences between them. ${ }^{155}$ The courts in Kenya as can be particularly seen from the Court of Appeal judgment in TSC v KNUT \& 3 others usually have not found a compromise whenever a conflict ensues between the teachers' right to strike and the children's right to education. ${ }^{156}$ They therefore need to work towards finding a middle ground that will ensure a balance between these two competing rights whenever a conflict arises.

In addition, Waldron provides that, when there is a conflict of human rights, a trade-off of the exercise of one right for the exercise of another right should not be undertaken. The courts whenever a conflict occurs should rather try to find a balance between the competing interests. ${ }^{157}$ The courts in Kenya should therefore not trade off the teachers' right to strike so as to allow children to exercise their right to education as seems to be the trend after the Court of Appeal judgment in Teachers Service Commission v Kenya National Union of Teachers \&. 3 others. ${ }^{158}$

Moreover, the main advantage of this approach is that it ensures a win-win situation. It does this by ensuring that the court balances both interests against each other and does not favour the weightier interest to the detriment of the other competing right. However, the main challenge with this approach is that the term balancing is vague. Thus, before the courts can claim to balance these competing interests there is a need for them to define what balancing entails. ${ }^{159} \mathrm{~A}$ meticulous focus on Article 24 of the Constitution, which is on how rights shall be limited, can assist here. This approach would hence be a suitable approach for courts in Kenya to employ for cases whereby there is a conflict between the teachers' right to strike and the children's right to education.

From the discussion above, there are indeed challenges faced by the courts in the interpretation of the best interest principle of the child. The balancing

\footnotetext{
Benditt M T 'Law and the balancing of interests' 3 Social Theory and Practice 3, 1975, 328.

(2015) eKLR.

$157 \mathrm{Xu}$ X and Wilson G, 'On conflict of Human rights' 5 University of New Hampshire Law Review 1, 2006, 49.

158 (2015) eKLR.

159 Möller K, 'Proportionality: Challenging the Critics' 10 International Journal of Constitutional Law 3, 2012,715 .
} 
approaches, particularly the approach on balancing competing interests, seem to be ideal models. They allow for not only the teachers to exercise their right to strike but also the children to enjoy their right to education.

\section{Conclusion and Recommendations}

Drawing evidence from the study above, the legal framework calls for respect and protection of both the teachers' right to strike and the children's right to education. However, the legal framework provides that both rights can be limited. ${ }^{160}$

Further, there are instances within the legal framework whereby the two competing rights are in conflict. Whenever these two rights are in conflict, the courts tend to rule in favour of the children's right to education as opposed to the teachers' right to strike. ${ }^{161}$ The courts usually issue injunctions which pulverise the teachers' right to strike; yet, this is the main means that they use to agitate for their pertinent needs. ${ }^{162}$

Furthermore, the courts, when determining cases between these two competing human rights, often rely on the best interest of the child principle. By relying on the best interest of the child principle, they tend to constantly rule in favour of the right to children's education over the teachers' right to strike. ${ }^{163}$ The courts, by doing so, seem to imply that the children's right to education is superior to the teachers' right to strike. Yet, the legal framework does not provide for this.

There are certain challenges that have been raised by several scholars concerning the interpretation of the best interest of the child principle. The main challenges are that there is no definition on what amounts to the best interest of the child principle and there are no guidelines on what factors should be considered when dealing with cases where there is a conflict between children's rights and other societal rights. ${ }^{164}$ These challenges pose a fundamental question as to whether courts should indeed always rule in favour of the children's right

\footnotetext{
Article 24, Constitution of Kenya (2010).

Teachers Service Commission v Kenya National Union of Teachers \& another (2012) eKLR.

Teachers Service Commission v Kenya National Union of Teachers \& 3 others (2015) eKLR.

Teachers Service Commission v Kenya National Union of Teachers, Ministry of Labour and Social Protection (Interested party) (2019) eKLR.

164 Mnookin R, 'Child custody adjudication: Judicial functions in the face of indeterminacy' 39 Law and Contemporary Problems 3, 1975, 260.
} 
to education whenever a conflict arises between this right and other fundamental human rights.

In a bid to address this conflict, several approaches have been suggested. One of these approaches is that the weightier interest shall always prevail in cases in which two human rights are in conflict. This approach favours one interest over the other and is hence not suitable for resolving the challenge at the heart of this paper. ${ }^{165}$ Another approach is the 'Minimum Core Services' approach, which requires employees to still meet the basic needs of the users of their services, even while on strike. Another approach is the balancing competing interests' approach. This approach encourages courts to look into the two competing rights and find a legal balance whenever a conflict arises. ${ }^{166}$

This paper recommends that, first, a definition of what amounts to the best interest of the child principle be provided for in the Convention of the Rights of the Child as the current definition is vague. This may also be provided in an Act of Parliament or via case law.

Secondly, this paper recommends that a set of guidelines for the best interest principle of the child should be developed. These guidelines may enable the courts to know how to apply the best interest principle in a manner that is just in cases of conflict between human rights such as the conflict between the teachers' right to strike and the right to children's education.

Lastly, this paper recommends that the courts should employ a more caseby-case approach when resolving cases concerning the conflict between the teachers' right to strike and the children's right to education. This may ensure that the courts take into consideration all the important circumstances surrounding each case thus ensuring that the interests of both teachers and the children are met.

To sum up, whenever the teachers' right to strike and the children's right to education are in conflict, the courts should not be quick to issue injunctions. Rather, they should compare the competing interests then proceed to balance them against each other.

\footnotetext{
165 Eskom Holdings Ltd v National Union of Mineworkers and others (2011), Supreme Court of Appeal of South Africa.

166 Luizzi V 'Balancing of interests in courts’ 20 Jurimetrics Journal 4, 1980, 383.
} 
